\title{
A report on the occurrence of Bangana dero (Hamilton, 1822) from Deepor beel (Ramsar site no. 1207), Brahmaputra valley, Assam
}

\author{
Simanku Borah \\ ICAR-Central Inland Fisheries Research Institute, Regional Centre, Housefed Complex, \\ Dispur, Guwahati-781006, India \\ Pronob Das* \\ ICAR-Central Inland Fisheries Research Institute, Regional Centre, Housefed Complex, \\ Dispur, Guwahati-781006, India \\ B.K. Bhattacharjya \\ ICAR-Central Inland Fisheries Research Institute, Regional Centre, Housefed Complex, \\ Dispur, Guwahati-781006, India

\section{A.K. Yadav} \\ ICAR-Central Inland Fisheries Research Institute, Regional Centre, Housefed Complex \\ Dispur, Guwahati-781006, India \\ B.J. Saud \\ ICAR-Central Inland Fisheries Research Institute, Regional Centre, Housefed Complex, \\ Dispur, Guwahati-781006, India \\ B.K. Das \\ ICAR-Central Inland Fisheries Research Institute, Barrackpore, Kolkata-700120, India \\ *Corresponding author. E-mail: pronobjaan80@gmail.com
}

\begin{abstract}
Deepor beel (Latitude: $26^{\circ} 05^{\prime} 26^{\prime \prime} \mathrm{N}$ to $26^{\circ} 09^{\prime} 26^{\prime \prime} \mathrm{N}$; Longitude: $90^{\circ} 36^{\prime} \mathrm{E}$ to $90^{\circ} 41^{\prime} 25^{\prime \prime} \mathrm{E}$ ) located in Kamrup district, Assam is a large (water spread area of 589 ha) natural wetland and a Ramsar site of international importance (Site number 1207 declared in 2002) having enormous biological and environmental importance. The wetland receives water from surface run-off as well as from two hill streams (Basistha and Kalamoni) and drains into River Brahmaputra, through a small rivulet (Khanajan). The beel supports a number of endemic endangered and threatened animals and plants that are included under IUCN red-list. Past studies indicated the occurrence of 67 fin-fish species in the beel. In a recent survey conducted by us, the beel Bangana dero (Synonyms: Cyprinus dero/ Labeo dero), a cyprinid fish, was collected for the first time from the beel. We collected as many as 28 specimens of $B$. dero from the beel during October 2016. The total length of the reported specimens ranged from $8.77-10.14 \mathrm{~cm}$ and weight ranged from $6.74-10.61 \mathrm{~g}$. The length-weight relationship of the species was worked out as $\mathrm{W}=0.074^{*} \mathrm{~L}^{2.103}$. B. dero reportedly inhabits upland rivers, torrential hill-streams; adults migrate to warm downstream regions during the winter season (December-February). Thus, the occurrence of this species in Deepor beel indicates its possible downstream migration from one or both the feeder rivers (Basistha and Kalamoni) or migration from Brahmaputra River through its connecting channel.
\end{abstract}

Keywords: Assam, Bangana dero, Deepor beel, Occurrence

\section{Article Info}

https://doi.org/10.31018/

jans.vi.2288

Received: May 5, 2020

Revised: May 29, 2020

Accepted: June 4, 2020

\section{How to Cite}

Borah, S. et al. (2020). A report on the occurrence of Bangana dero (Hamilton, 1822) from Deepor beel (Ramsar site no. 1207), Brahmaputra valley, Assam. Journal of Applied and Natural Science, 12 (2): 202 - 206.

https://doi.org/10.31018

jans.vi.2288

\section{INTRODUCTION}

Floodplain wetlands are primarily formed by river meandering activity and are situated in the floodplains of rivers. India has a wealth of floodplain wetland ecosystems that support diverse and unique habitats. Floodplain wetlands are locally known as beels in Assam and cover an estimated area of over 100,000 ha (Das et al., 2009, 2017, 2018). Deepor beel $\left(26^{\circ} 05^{\prime} 26^{\prime \prime} \mathrm{N}\right.$ to $26^{\circ} 09^{\prime} 26^{\prime \prime} \mathrm{N}$ Latitude and $90^{\circ} 36^{\prime} \mathrm{E}$ to $90^{\circ} 41^{\prime} 25^{\prime \prime} \mathrm{E}$ Longitude) located $10 \mathrm{~km}$ south-west of Guwahati city,
Kamrup district, Assam is one of the large natural wetland with water spread area of 589 ha (Acharjee et al., 2009), a Ramsar site of international importance (Site number: 1207) declared in 2002 and have great biological and environmental importance (Deka and Goswami, 1992). The wetland receives drainage from rainfall runoff and from Basistha and Kalamoni, which are torrential rivers and drains into the mighty Brahmaputra River, through a small rivulet called Khanajan.This wetland is a site of rich floral and faunal 
diversity (Saikia, 2005). With regard to ichthyofaunal diversity, this wetland supports 54 indigenous and 5 exotic fish species (Saikia, 2005). Acharjee et al. (2009) reported the occurrence of 46 species belongings to 17 families. Bhattacharjya et al. (2014) reported a total of 67 fin-fish species from this wetland, an increase over the years. Cyprinids are the numerically most abundant primary freshwater family in the Indo-Burma region (Kottelat et al., 2012) and this holds true for this wetland too with $46.3 \%$ of the total fish species being represented by cyprinids. This paper records the occurrence of Bangana dero (Hamilton, 1822; Synonyms: Cyprinus dero/ Labeo dero) in Deepor beel, categorised as least concern as per IUCN (2017), commonly known as Kalabans, locally known as Nepura in Assam and comments upon the possible mode of introduction. Thus, the total number of fin-fish species recorded from Deepor beel stands at 68 and the total number of cyprinids at 32 .

\section{MATERIALS AND METHODS}

A total of 28 specimens of Bangana dero (Fig. 1) were collected from Azara landing centre $\left(26^{\circ} 13^{\prime} 03^{\prime \prime} \mathrm{N}\right.$ and $\left.91^{\circ} 58^{\prime} 28^{\prime \prime} \mathrm{E}\right)$ of the Deepor beel (Fig. 2) during October 2016. The specimens were caught by fishers using dragnet of $5-10 \mathrm{~mm}$ mesh size and brought to the landing centre. The collected specimens were identified with the help of published manuals (Talwar and Jhingran, 1991; Vishwanath et al., 2007). Representative specimens are preserved in Aquatic Biology laboratory of ICAR-CIFRI Regional Centre, Guwahati in formalin (10\%) and ethanol (70\%) following Biswas (1992)

\section{RESULTS}

The present study reported that the total length of the reported specimens ranged from $8.77-10.14$ $\mathrm{cm}$ and weight ranged from $6.74-10.61 \mathrm{~g}$. Descriptive statistics of morphometric traits for the

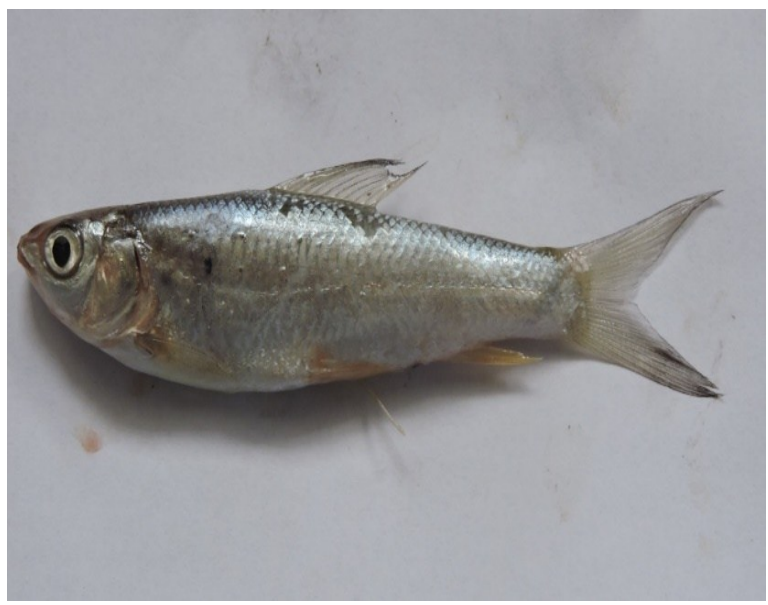

Fig. 1. Bangana dero (Hamilton, 1822).

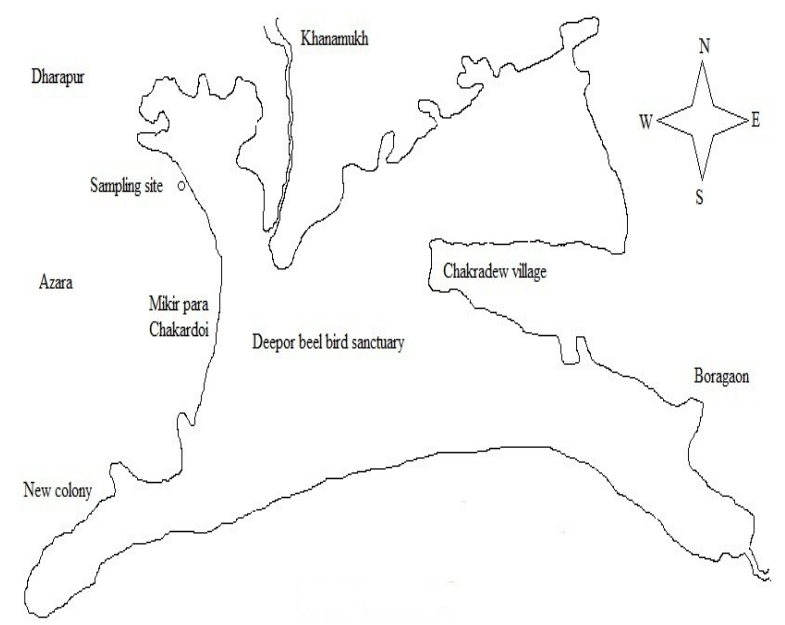

Fig. 2. Specimens collection site (Azara landing centre, Deepor beel, Guwahati, Assam).

collected specimens and respective body proportions in relation to total length (mean values) are presented in Table 1. With regard to the meristic characters, 41 - 44 scales were found along the lateral line and fin formula was found to be $D$ ii-iii 10-12; A ii-iii 5-6; P i 14-16; V i 7-8. Frequency distributions of different meristic characters of the collected specimens are given in Table 2. The length-weight relationship was worked out as $\mathrm{W}=$ $0.074^{*} \mathrm{~L}^{2.403}$.

\section{DISCUSSION}

$B$. dero is distributed throughout the Himalayan foothills in India, Nepal, and China as well as reported from Bangladesh (IUCN, 2017). It has been introduced in peninsular India and Sri Lanka. This species inhabits mainly in upland rivers, torrential hill-streams, particularly in shallow waters (Talwar and Jhingran, 1991) and is potamodromous by nature (Riede, 2004). These species migrate to warm regions such as downstream of rivers and warmer lakes during the winter season (Raina and Petr, 1999) to survive the low temperature in high altitudes. The lower and upper elevation limits for this species are reported to be $135 \mathrm{msl}$ and 1424 msl, respectively (IUCN, 2017). The major river flowing into this water body is Basistha which is a shallow, torrential stream originating in the Meghalaya foothills and occurrence of this species in the beel might be due to such downstream winter migration from connecting rivers. However, it could not be verified whether $B$. dero is reported from Basistha river and adjoining hill streams draining into this wetland as limited work has been done on the ichthyofaunal diversity of these rivers and thus studies on fish diversity of these rivers is essential to ascertain the fact. $B$. dero is a commercially important minor carp of Brahmaputra river in Assam (Bhattacharjya et al., 2017) and there are also possibilities that this species might have migrated from the River Brahmaputra into 
Borah, S. et al. / J. Appl. \& Nat. Sci. 12(2): 202 - 206 (2020)

Table 1. Descriptive statistics of morphometric traits of $B$. dero collected from Deepor beel.

\begin{tabular}{|c|c|c|c|c|c|}
\hline Traits (cm) & Maximum & Minimum & Mean $\pm S E$ & $\begin{array}{l}\text { Coefficient of } \\
\text { variation (\%) }\end{array}$ & $\begin{array}{l}\% \text { of total } \\
\text { length (mean } \\
\text { values) }\end{array}$ \\
\hline Total length & 10.14 & 8.77 & $9.61 \pm 0.07$ & 3.90 & 100.00 \\
\hline Head length & 1.99 & 1.69 & $1.82 \pm 0.01$ & 3.87 & 18.94 \\
\hline Eye diameter & 0.6 & 0.44 & $0.51 \pm 0.01$ & 7.63 & 5.31 \\
\hline $\begin{array}{l}\text { Pre dorsal fin } \\
\text { length }\end{array}$ & 3.69 & 3.06 & $3.38 \pm 0.03$ & 4.63 & 35.17 \\
\hline Standard length & 8.07 & 6.9 & $7.52 \pm 0.05$ & 3.77 & 78.25 \\
\hline Fork length & 8.99 & 7.52 & $8.28 \pm 0.07$ & 4.21 & 86.16 \\
\hline Body depth & 2.07 & 1.67 & $1.94 \pm 0.02$ & 4.84 & 20.19 \\
\hline $\begin{array}{l}\text { Depth of caudal } \\
\text { peduncle }\end{array}$ & 0.9 & 0.72 & $0.81 \pm 0.01$ & 5.52 & 8.43 \\
\hline Snout length & 0.59 & 0.38 & $0.49 \pm 0.01$ & 10.86 & 5.10 \\
\hline $\begin{array}{l}\text { Pre pelvic } \\
\text { length }\end{array}$ & 4.1 & 3.6 & $3.88 \pm 0.02$ & 3.08 & 40.37 \\
\hline $\begin{array}{l}\text { Pre pectoral } \\
\text { length }\end{array}$ & 1.91 & 1.52 & $1.74 \pm 0.02$ & 6.58 & 18.11 \\
\hline $\begin{array}{l}\text { Pre anal fin } \\
\text { length }\end{array}$ & 6.16 & 5.28 & $5.71 \pm 0.04$ & 3.78 & 59.42 \\
\hline $\begin{array}{l}\text { Height of the } \\
\text { dorsal fin }\end{array}$ & 1.91 & 1.37 & $1.70 \pm 0.02$ & 7.63 & 17.69 \\
\hline
\end{tabular}

the wetland through the connecting channel. This species has not been reported from this wetland prior to the present findings. $B$. dero prefers a water temperature range of $19.5-25.5^{\circ} \mathrm{C}$ (Nath, 1994). As per air temperature data collected from Regional Meteorological Centre, Guwahati, the monthly mean air temperature in Guwahati station during September 2016 was $29.4^{\circ} \mathrm{C}$ which decreased to $27.6^{\circ} \mathrm{C}$ in October and further dropped to $23.4^{\circ} \mathrm{C}$ during November 2016 . The drop in air temperature corresponds to drop in water temperature and there is a possibility that temperature decline in the hill streams beyond its favourable range has resulted in the downstream migration of this species to warmer waters of the wetland, where water temperature on the date of sampling date was found to be within its favourable range $\left(23.3^{\circ} \mathrm{C}\right)$. Another aspect is the feeding cessation due to drop in temperature in $B$. dero and subsequent downstream migration to warmer waters. This has been observed in L. dyocheilus, another similar migratory hill stream fish which showed highest body weight gain owing to higher feeding intensity in the temperature range of $20-22^{\circ} \mathrm{C}$ as compared to $18-20^{\circ} \mathrm{C}$ and $16-18^{\circ} \mathrm{C}$ when reared in captivity (Verma, 2015). It should be noted that the species might have migrated to this wetland in the years before as well, but it is the first instance of this species being reported from Deepor beel. A number of studies have been made on the lengthweight relationship of fin-fish species from Brahmaputra basin, Ganga basin and Peninsular rivers of India (Nath et al., 2017; Baitha et al., 2018; Koushlesh et al., 2018; Borah et al., 2018; Nath et al., 2019; Mol et al., 2019; Borah et al., 2019). Studies on the length-weight relationship showed $b$ value of 2.403 and $a$ value of 0.074 . The value of $b$ is outside the normal range of 2.5-3.5, as suggested by Froese (2006). The multitude of factors either singly or in combination such as a number of specimens examined; fish habitat; the degree of stomach fullness; sex; stage of gonadal maturity; and differences in the observed length range of the specimens cause variations in observed $b$ values (Froese, 2006). In the present study, $b$ value which is outside the normal range may be attributed to being a limited sample size, narrow variations in size groups in observed specimens and limited sampling period. Length-weight relationship of 6 indigenous fish species from Deepor beel with larger sample size, revealed $b$ value within the normal range of 2.778 to 3.215 (Borah et al., 2017).

\section{Conclusion}

B. dero is a commercially important minor carp of Brahmaputra River in Assam. It is an important food and game fish and has a ready demand in the local market with a better price than Indian major carps. The occurrence of this species in Deepor beel indicates its possible downstream migration from one or both the feeder rivers (Basistha and Kalamoni). There are also possibilities that this species might have migrated from river Brahmaputra into the wetland through the connecting channel. This species has not been reported from this wetland prior to the present findings. Thus, the present finding adds to a num- 
Borah, S. et al. / J. Appl. \& Nat. Sci. 12(2): 202 - 206 (2020)

ber of fin-fishes recorded from wetland with the total number standing at 68 and the number of cyprinids at 32 . The findings of the study will be helpful in conservation of fish diversity from this important Ramsar site.

\section{ACKNOWLEDGEMENTS}

The financial support sanctioned by Indian Council of Agricultural Research (ICAR), New Delhi, India to carry out the work under the Institutional Research Project of ICAR-CIFRI is gratefully acknowledged.

\section{REFERENCES}

1. Acharjee, B., Dutta, A., Sharma, D. K., Das, P. \& Behera, B.K. (2009). Ecological status of Deepor Beel, Assam with special reference to its fish and fisheries. In: Ecology, Aquatic Bio-resources and conservation of wetlands of North east India (ed. Kosygin, L.). Akansha Publishing House, New Delhi, pp. 41-54 (ISBN 978-81-8370-187-7).

2. Baitha, R., Sinha, A., Koushlesh, S. K., Chanu, T. N., Kumari, K., Gogoi, P., Ramteke, M. H., Borah, S. \& Das, B. K. (2018). Length-weight relationship of ten indigenous freshwater fish species from Gandak River, Bihar, India Journal of Applied Ichthyology, 34 (1), 233-236. https://doi.org/10.1111/jai.13555.

3. Baruah, P., Deka, C. R. \& Goswami, D. C. (1992). Study of Seasonal variation in Water spread and Land use Pattern in the Deepor Beel Area Using Digital Image Processing and GIS Techniques. Proceedings of Zoological Society of Assam, Special edition, 34-48.

4. Bhattacharjya, B. K., Bhaumik, U. \& Sharma, A.P. (2017). Fish habitat and fisheries of Brahmaputra River in Assam, India. Aquatic Ecosystem Health and Management, 20, 102-115. https:// doi.org/10.1080/14634988.2017.1297171

5. Bhattacharjya, B. K., Saud, B. J., Sharma, A. P. \& Goswami, U. C. (2014). Eco-Hydrobiology and Fisheries of Deepor: A Ramsar Site of North East India with a Note on its Conservation. In: Advances in Fisheries Research, Vol. 6. Narendra Publishing House, Delhi, pp. 293-314.

6. Biswas, S.P. (1992). Manuals of Methods in Fish Biology (pp. 12, 13, 131). New Delhi: South Asian Publishers Pvt. Ltd.

7. Borah S., Bhattacharjya B.K., Saud B.J., Yadav A.K., Debnath D., Yengkokpam S., Das P., Sharma N., Singh N. S. \& Sarma K. K. (2017). Length-weight relationship of six indigenous fish species from Deepor beel, a Ramsar site in Assam, India. Journal of Applied Ichthyology, 33: 655-657. https:// doi.org/10.1111/jai.13348.

8. Borah, S., Gogoi, P., Bhattacharjya, B.K., Suresh V.R., Yadav, A.K., Baitha, R., Koushlesh, S.K., Kakati, A., Ray, B.C. \& Das, B.K. (2018). Length-weight and length-length relationship of two endemic snakehead fish species from Brahmaputra river basin, Assam, India. J. Appl. Ichthyol., 34(3): 788-790. https:// doi.org/10.1111/jai.13685.

9. Borah, S., Vaisakh, G., Jaiswar, A.K., Bhattacharjya, B.K., Sahoo, A.K., Deshmukhe, G., Raman, R.K. and Das, B.K. (2019). Length-weight relationship and condition factor of three geographically isolated pop- 
ulations of Hilsa Shad, Tenualosa ilisha (Hamilton, 1822). Journal of the Inland Fisheries Society of India, 51(1): 49-54.

10.Das, B. K., Bhattacharjya, B. K., Borah, S., Das, P., Debnath, D., Yengkokpam, S., Yadav, A. K., Sharma, N., Singh, N. S., Panit, A., Ekka, A., Mishal, P., Karnatak, G., Kakati, A., Saud, B. J. \& Das, S. S. (2017). Roadmap for Development of Openwater Fisheries in Northeastern States. ICAR-CIFRI, Policy paper No. 6. pp.101 (ISSN: 0970-616X).

11.Das, P., Behera, B. K. \& Ngachan, S.V. (2009). Beels of Assam - an overview. In: Ecology, Aquatic Bio-resources and conservation of wetlands of North east India (ed. Kosygin, L.). Akansha Publishing House, New Delhi, pp. 29-40 (ISBN 978-81-8370187-7).

12.Das, P., Borah, S., Yadav, A. K., Bhattacharjya, B. K. \& Das, B. K. (2018). Openwater fisheries of Assam and strategies for its development. Fishing Chimes, 38(1\&2): 17-28.

13.Deka, S. K. \& Goswami, D. C. (1992). Hydrology, Sediment Characteristics and Depositional Environment of Wetlands: A case study of Deepor Beel, Assam. J. Assam. Sc. Soc., 34(2): 62-84.

14.Froese, R. (2006). Cube law, condition factor and weight-length relationships: history, meta-analysis and recommendations. J. Appl. Ichthyol., 22: 241253. https://doi.org/10.1111/j.1439-0426.2006.008 05.x.

15. Hamilton, F. (1822). An account of the fishes found in the river Ganges and its branches (405 pp.). Edinburgh, London: Archibald Constable and Co.

16.IUCN (2017). The IUCN Red List of Threatened Species version 2017-3. Retrieved from http:// www.iucnredlist.org (accessed on 29 December 2017).

17. Koushlesh SK, Sinha A, Kumari K, Borah S, Chanu TN, Baitha R, Das SK, Gogoi P, Sharma SK, Ramteke MH, Das BK (2018) Length-weight relationship and relative condition factor of five indigenous fish species from Torsa River, West Bengal, India. J. Appl. Ichthyol., 34(1): 169-171. https:// doi.org/10.1111/jai.13518.

18.Kottelat, M., Baird, I. G., Kullander, S. O., Ng, H. H., Parenti, L. R., Rainboth, W.J., \& Vidthayanon, C. (2012). The status and distribution of freshwater fishes of Indo-Burma. In: The status and distribu- tion of freshwater biodiversity in Indo-Burma. IUCN, Cambridge \& Gland, pp. 38-65.

19.Mol, S.S., Jaiswar, A.K., Panikkar, P., Behera, B.K., Kumar, H.S., Roshith, C.M., Vijaykumar, M.E., Sharma, S.K., Manna, R.K. \& Das, B.K. (2019). Lengthweight relationship and relative condition factor of five Labeo spp. from river Cauvery in India. Indian Journal of Fisheries, 66(2): 115-119. DOI: 10.21077/ ijf.2019.66.2.89003-16.

20.Nath, S. (1994). Recent Advances in Fish Ecology, Limnology and Eco-conservation, Vol. 3. Daya Publishing House, Delhi, India p. 44.

21.Nath, B,B,, Das, J., Ahmed, A.M., Sarma, J., Phukan, B., Ali, A., Sharma, A.K. \& Borah, S. (2019). Lengthweight and length-length relationship of two tropical freshwater fish species from central Brahmaputra valley, Assam. J. Exp. Zool. India, 22(1): 321-324.

22.Nath, K.D., Borah, S., Yadav, A.K., Bhattacharjya, B.K., Das, P., Deka, P.M., Darngawn, O. \& Nath, D.J.D. (2017). Length-weight and length-length relationship of four native fish species from Barak River, Assam, India. J. Exp. Zool. India, 20(2): 977-979.

23.Raina, H. S. \& Petr, T. (1999). Coldwater fish and fisheries in the Indian Himalayas: lakes and reservoirs. In: Fish and fisheries at higher altitudes: Asia. FAO Fisheries Technical Paper No 385, FAO, Rome, pp. 64-88.

24.Riede, K. (2004). Global register of migratory species - from global to regional scales Bonn, Germany: Federal Agency for Nature Conservation, p.329.

25.Saikia, P. K. (2005). Quantitative and qualitative study of lower and higher organisms and their functional role in the Deepor beel ecosystem. NorthEastern Space Application Centre, Department of Space Government of India, Umium, Shillong, Meghalaya, p. 97.

26. Talwar, P. K. \& Jhingran, A. G. (1991). Inland fishes of India and adjacent countries, Vols.1\&2, Oxford and IBH Publishing Co., Pvt. Ltd., New Delhi, India, p. 1158.

27.Verma, R. (2015). Biological study is an approach towards conservation of a species: a case study in Labeo dyocheilus at Central Himalaya province. International Journal of Science, Technology \& Management, 4, 133-143.

28.Vishwanath, W., Lakra, W. S., \& Sarkar, U. K. (2007). Fishes of North East India. ICAR-National Bureau of Fish Genetic Resources, Lucknow, p.290. 